\section{Elimination Kinetics of $\propto$-Amino-iso- butyric Acid in Non-Pregnant and Pregnant Rabbits}

CHANGes in the maternal metabolic and excretory functions occur during pregnancy; the plasma elimination rates of many compounds, such as folic acid ${ }^{1,2}$, cortisol $^{3-5}$, nalidixic acid or gentamycin ${ }^{6}$, have been found to differ in non-pregnant and pregnant subjects. Also, the plasma steady state concentration of most of the free amino acids is already lowered early in pregnancy. Here I report on the elimination rate of the model $\alpha$-amino-iso-butyric acid (AIB) in pregnant and non-pregnant rabbits. I chose this amino acid because it is not metabolized ${ }^{7,8}$; it is transported and distributed throughout the body by the same mechanism as the naturally occurring
The elimination curve of ${ }^{3} \mathrm{H}$-AIB does not seem to be linear on the semilogarithmic scale and therefore first order kinetics are not applicable for the characterization of the disappearance of this substance from the plasma of nonpregnant and pregnant rabbits. It is, however, possible to show $^{14}$ that the experimentally obtained data closely fit a third order elimination model represented by

$$
y=C_{1} e^{-\alpha t}+C_{2} e^{-\beta t}+C_{3} e^{-\gamma t}
$$

where the elimination constants are $\alpha=0.52, \beta=0.14, \gamma=0.008$. Because I assume that the metabolic and excretory functions of the animals do not change during the periods of experiment, this indicates that the elimination of ${ }^{3} \mathrm{H}$-AIB is determined simultaneously by the kinetic properties of three different compartments.

Fig. 1 Plasma elimination curve of ${ }^{3} \mathrm{H}$-AIB in rabbits.

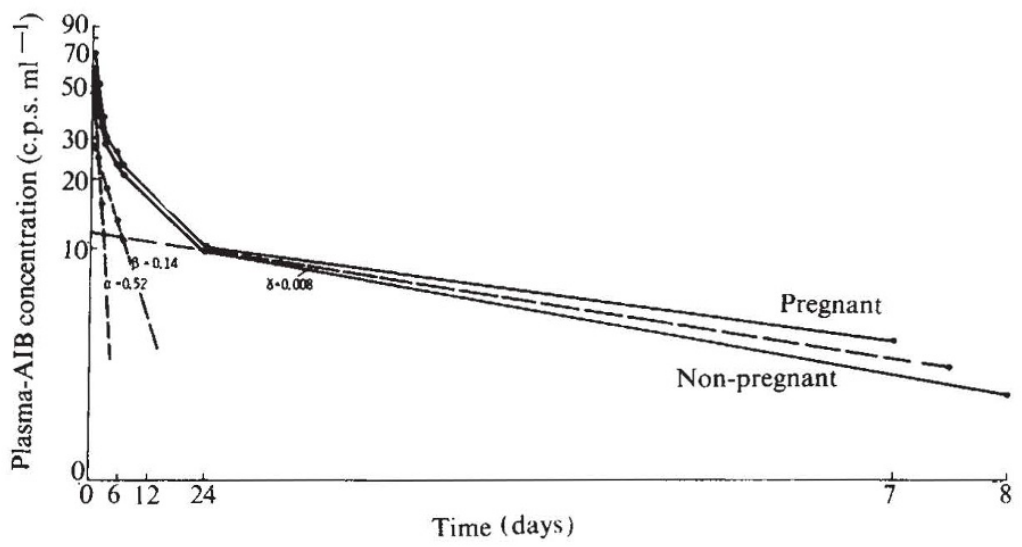

free amino acids preferring the A-mediating system ${ }^{9,10}$; it is slowly and almost exclusively excreted by the kidneys ${ }^{7,8,11}$; and it is believed to accumulate in fast growing foetal tissue ${ }^{12,13}$. Twenty-one experiments were performed using nine rabbits. Ten experiments were carried out in the non-pregnant and eleven in the pregnant animal. The pregnant rabbits were investigated in the first and third weeks of gestation.

A single dose of tritiated AIB $\left({ }^{3} \mathrm{H}-\mathrm{AIB}\right.$, specific activity $1.8 \mathrm{Ci} \mathrm{mmol}-1$ ) was administered intravenously. Blood samples were then drawn from the ear vein after $30,70,130$, 180,310 and $400 \mathrm{~min}$. Two additional samples were collected after $\sim 24 \mathrm{~h}$ and 1 week. The plasma ${ }^{3} \mathrm{H}$-AIB concentration was measured in a Packard Tricarb Scintillation Counter.

Table 1 Plasma ${ }^{3} \mathrm{H}$-AlB Concentrations at Different Times after Injection of a Single Dose $(45 \mu \mathrm{Ci})$ into Non-Pregnant and Pregnant Rabbits

\begin{tabular}{ccc}
$\begin{array}{c}\text { Time after } \\
\text { injection }(\mathrm{min})\end{array}$ & $\begin{array}{c}\left.{ }^{3} \mathrm{H}-\mathrm{AIB} \text { concentration (c.p.s. } \mathrm{ml}^{-1}\right)(\operatorname{mean} \pm \text { s.e. } \\
\text { Non-pregnant }(n=8)\end{array}$ \\
$\begin{array}{ccc}\text { Pregnant }(n=4) \\
30\end{array}$ & $57.2 \pm 2.9$ & $68.7 \pm 5.8$ \\
70 & $42.2 \pm 3.0$ & $51.1 \pm 9.1$ \\
130 & $33.9 \pm 2.1$ & $37.6 \pm 3.8$ \\
180 & $28.9 \pm 1.8$ & $30.9 \pm 2.6$ \\
310 & $23.2 \pm 1.6$ & $26.6 \pm 2.4$ \\
400 & $21.3 \pm 1.4$ & $23.0 \pm 2.2$ \\
$24 \mathrm{~h}$ & $9.8 \pm 1.2(n=10)$ & $10.3 \pm 0.7(n=11)$ \\
\hline
\end{tabular}

Table 1 and Fig. 1 summarize my results. In the pregnant rabbits the plasma concentrations are generally higher and the elimination slightly slower than in the non-pregnant. There is, however, no statistically significant difference between the two groups of animals, and the results for the different stages of pregnancy are also similar.
Henriques et al. ${ }^{15}$, measuring the elimination rate of the naturally occurring free amino acid glycine in non-pregnant rabbits, came to similar conclusions. They were unable to find a single value for the plasma half-life of glycine and also suggested that at least three body compartments have an influence on the elimination kinetics of this particular amino acid.

Department of Gynaecology,

Felix Krauer

St Thomas's Hospital Medical School,

London $S E 1$

Received December 12, 1972.

${ }^{1}$ Chanarin, I., McGibbon, B. M., O'Sullivan, W. J., and Mollin, D. L., Lancet, ii, 634 (1959)

${ }^{2}$ Landon, M. J., and Hytten, F. E., J. Obstet. Gynaec. Brit. Cwlth., 78, 769 (1971).

${ }^{3}$ Migeon, C. J., Bertrand, J., and Wall, P. E., J. Clin. Invest., 36, 1350 (1957).

${ }^{4}$ Migeon, C. J., Kenny, F. M., and Taylor, F. H., J. Clin. Endocrinol., 28, 661 (1968).

5 Sandberg, A. A., and Slaunwhite, W. R., J. Clin. Invest., 38, 1290 (1959).

${ }^{6}$ v. Kobiletzky, D., Med. Welt, 38, 2010 (1968).

7 Noall, M. W., Riggs, T. R., Walker, L. M., and Christensen, H. N., Science, 126, 1002 (1957).

${ }^{8}$ Christensen, H. N., and Jones, J. C., J. Biol. Chem., 237, 1203 (1962).

9 Oxender, D. L., and Christensen, H. N., Nature, 197, 765 (1963).

10 Oxender, D. L., and Christensen, H. N., J. Biol. Chem., 238, 3668 (1963)

11 Christensen, H. N., and Clifford, J. A., Biochim. Biophys. Acta, 62, 160 (1962).

12 Christensen, H. N., and Streicher, J. A., J. Biol. Chem., 175, 95 (1948).

13 Christensen, H. N., Thompson, D. H., Martel, S., and Sidkey, M., Proc. Soc. Exp. Biol. Med., 99, 780 (1958).

14 Solomon, A. K., J. Clin. Invest., 28, 1297 (1949).

15 Henriques, O. B., Henriques, S. B., and Neuberger, A., Biochem. J., 60, 409 (1955). 